\title{
Porphyria: What Is It and Who Should Be Evaluated?
}

\author{
Yonatan Edel, M.D. ${ }^{1,2,3 *}$ and Rivka Mamet, Ph.D. ${ }^{1}$ \\ ${ }^{1}$ Porphyria Center, Rabin Medical Center, Beilinson Hospital, Petach Tikva, Israel; ${ }^{2}$ Rheumatology Unit, \\ Rabin Medical Center, Beilinson Hospital, Petach Tikva, Israel; and ${ }^{3}$ Sackler Faculty of Medicine, Tel \\ Aviv University, Tel Aviv, Israel
}

\begin{abstract}
The porphyrias are a group of rare metabolic disorders, inherited or acquired, along the heme biosynthetic pathway, which could manifest with neurovisceral and/or cutaneous symptoms, depending on the defective enzyme. Neurovisceral porphyrias are characterized by acute attacks, in which excessive heme production is induced following exposure to a trigger. An acute attack usually presents with severe abdominal pain, vomiting, and tachycardia. Other symptoms which could appear include hypertension, hyponatremia, peripheral neuropathy, and mild mental symptoms. In severe attacks there could be severe symptoms including seizures and psychosis. If untreated, the attack might become very severe, affecting the peripheral, central, and autonomic nervous system, leading to paralysis, respiratory failure, hyponatremia, coma, and even death. From the biochemical point of view, acute attacks are involved with increased levels of precursors in the heme biosynthetic pathway, up to the deficient step. Of these precursors, aminolevulinic acid (ALA) is considered to be neurotoxic. Treatment is directed to reduce ALA production by reducing the activity of the enzyme aminolevulinate synthase (ALAS) - most effectively by heme therapy. Cutaneous symptoms are a consequence of elevated porphyrins in the blood stream. These porphyrins react to light;
\end{abstract}

\begin{abstract}
Abbreviations: ADP, aminolevulinic acid dehydratase porphyria; AIP, acute intermittent porphyria; ALA, aminolevulinic acid; ALAD, aminolevulinic acid dehydratase; ALAS, aminolevulinate synthase; CEP, congenital erythropoietic porphyria; COPRO III, coproporphyrinogen III; CPOX, coproporphyrinogen oxidase; EPP, erythropoietic protoporphyria; $\mathrm{Fe}^{2+}$, iron; FECH, ferrochelatase; HCP, hereditary coproporphyria; HEP, hepato-erythropoietic porphyria; HMB, hydroxymethylbilane; HMBS, hydroxymethylbilane synthase; PBG, porphobilinogen; PCT, porphyria cutanea tarda; PPOX, protoporphyrinogen oxidase; PROTO'gen IX, protoporphyrinogen IX; URO III, uroporphyrinogen III; UROD, uroporphyrinogen decarboxylase; UROS, uroporphyrinogen-III synthase; VP, variegate porphyria; XLPP, Xlinked protoporphyria.
\end{abstract}

Citation: Edel Y, Mamet R. Porphyria: What Is It and Who Should Be Evaluated?. Rambam Maimonides Med J 2018;9 (2):eo013. Review. doi:10.5041/RMMJ.10333

Copyright: (C) $2018 \mathrm{Edel}$ and Mamet. This is an open-access article. All its content, except where otherwise noted, is distributed under the terms of the Creative Commons Attribution License (http://creativecommons.org/licenses/by/3.0), which permits unrestricted use, distribution, and reproduction in any medium, provided the original work is properly cited.

Conflict of interest: No potential conflict of interest relevant to this article was reported.

* To whom correspondence should be addressed. E-mail: yonatanad@clalit.org.il 
therefore sun-exposed areas are affected, producing fragile erosive skin lesions in porphyria cutanea tarda (PCT) or non-scarring stinging and burning symptoms in erythropoietic protoporphyria (EPP). Unlike the most common neurovisceral porphyria, acute intermittent porphyria (AIP), variegate porphyria (VP), and hereditary coproporphyria (HCP) can have cutaneous symptoms as well. Differentiating them from other cutaneous porphyrias is essential for accurate diagnosis, treatment, and patient recommendations.

KEY WORDS: Aminolevulinic acid, porphobilinogen, porphyria

\section{INTRODUCTION}

The porphyrias are a group of rare metabolic disorders-either inherited or acquired along the heme biosynthetic pathway. ${ }^{1,2}$ Each type of porphyria is a result of a specific deficiency in one of the enzymes involved in the pathway (Figure 1) and, accordingly, is characterized by a specific pattern of accumulation of heme precursors and typical clinical manifestations.

Historically, porphyrias have been subdivided into hepatic and erythropoietic forms, according to the site of expression of the dysfunctional enzyme. However, in a clinical approach, it is much more convenient to classify them according to their clinical manifestations - as acute (neurovisceral) versus non-acute (cutaneous) porphyrias. ${ }^{3}$ In some of the acute porphyria types both neurovisceral and cutaneous symptoms may be present.

The acute neurovisceral forms are characterized by overproduction of delta-aminolevulinic acid (ALA) and porphobilinogen (PBG), which are porphyrin precursors, at the initial steps of heme synthesis4,5 (Figure 1), while the cutaneous ones are characterized by accumulation of porphyrins, which are the precursors at the final steps of the synthesis. ${ }^{6}$ This fundamental difference is the basis of the different clinical symptoms.

The accumulated precursors are excreted in the urine, in the feces, or in both-according to their solubility-and measuring their level is the basis of porphyria biochemical diagnosis and typing.7

Heme, the final product of the pathway, is essential for the synthesis of hematoproteins such as hemoglobin, myoglobin, microsomal cytochromes, catalase and others-all of which play an important role in oxygen transport and/or oxidation-reduction reactions. Most of heme synthesis in human beings (80\%) takes place in erythropoietic cells, while about $15 \%$ is produced in the liver parenchymal cells. In both tissues, the synthesis is controlled, although differently. 3
The first step in the synthesis, ALA formation (Figure 1), is the most important site of control. This step is catalyzed by the enzyme ALA synthase (ALAS), which has two subtypes-ALAS1, the ubiquitous one, encoded on chromosome 3, and ALAS2, erythroid-specific, encoded on chromosome X. In the erythropoietic tissue, regulation of heme synthesis is influenced by erythroid differentiation and erythropoietin and iron availability, while in the liver, ALAS1 is under negative feedback regulation by the intracellular heme pool. 3 This regulatory mechanism is the basis of strategies in treatment and management of porphyria patients.

In this review we will summarize the different characteristics of each of the porphyrias: clinical manifestations, diagnosis, and treatment options.

\section{ACUTE PORPHYRIAS}

The group of acute porphyrias includes four types of porphyria: acute intermittent porphyria (AIP), which is the most common one; hereditary coproporphyria (HCP); variegate porphyria (VP); and the rarest one, aminolevulinic acid dehydratase porphyria (ADP), of which only six definite cases have been reported so far and will be discussed later.

Two of these four diseases, HCP and VP, are associated with both acute attacks and skin bullous lesions, ${ }^{8}$ similar to those of non-acute cutaneous porphyrias, which will be discussed later in this review.

Acute intermittent porphyria (AIP), HCP, and VP are inherited in an autosomal dominant way and result from a deficiency of one of the enzymes, hydroxymethylbilane synthase (HMBS), coproporphyrinogen oxidase (CPOX), and protoporphyrinogen oxidase (PPOX), respectively (Figure 1). Since the deficiency is inherited from one affected parent, in all three porphyrias, the residual enzyme activity is about 50\%, which is sufficient for regular heme homeostasis, ${ }^{9}$ keeping the disease latent. In fact, most patients will remain asymptomatic during their 


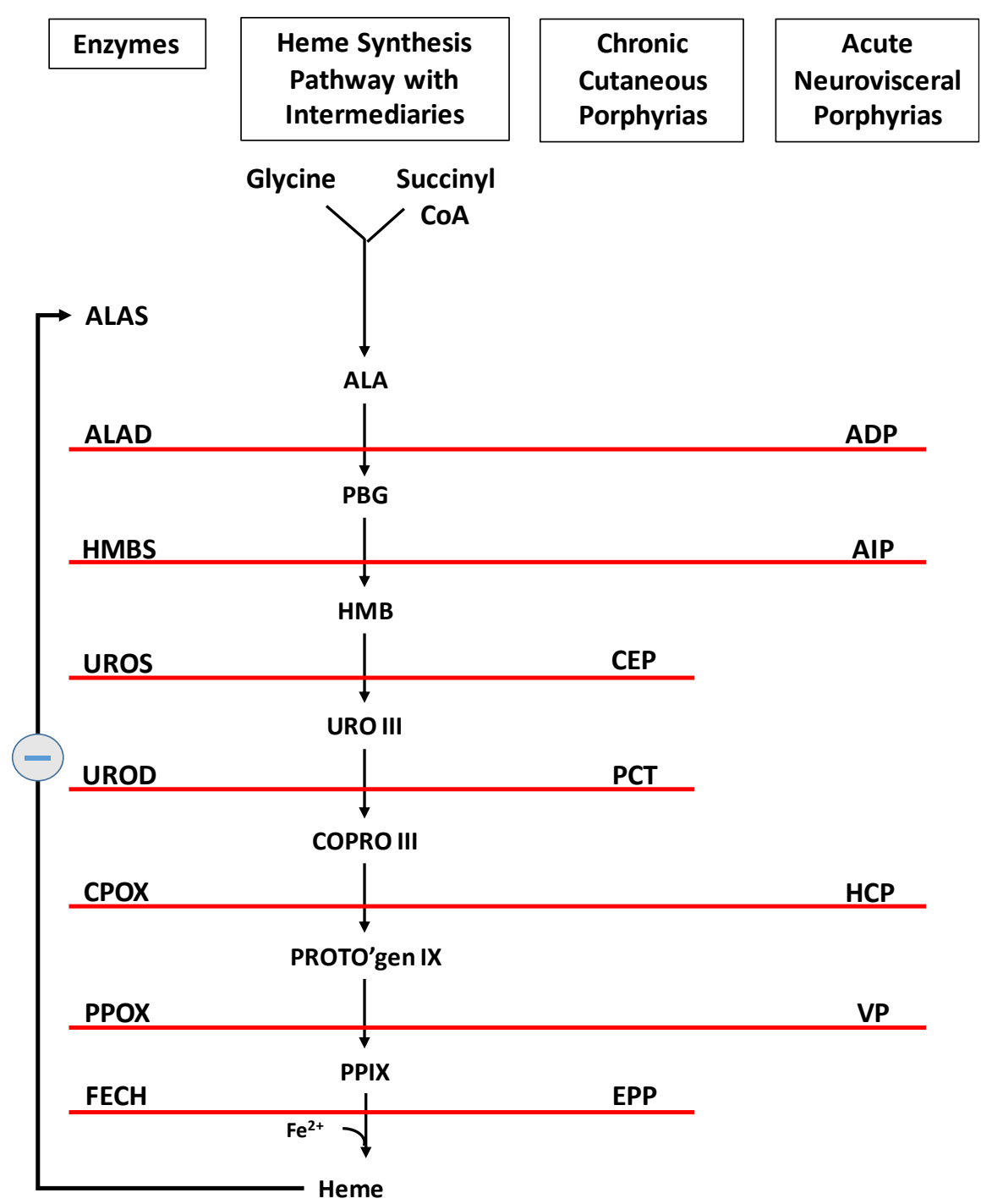

Figure 1. The Heme Synthesis Pathway: Enzymes Involved in the Pathway and the Associated Porphyrias with the Disruption of Each Specific Enzyme.

Main (center) core: Precursors and intermediary products in the heme synthesis pathway. (ALA, aminolevulinic acid; PBG, porphobilinogen; HMB, hydroxymethylbilane; URO III, uroporphyrinogen III; COPRO III, coproporphyrinogen III; PROTO’gen IX, protoporphyrinogen IX; PPIX, protoporphyrin IX; Fe2+, iron.)

Left of the core: Enzymes, encoded by genes, catalyze each of the steps. Gene mutations cause deficient enzyme production. Disruptions are indicated by red lines connecting enzymes with the resultant porphyrias. (ALAS, aminolevulinate synthase; ALAD, aminolevulinic acid dehydratase; HMBS, hydroxymethylbilane synthase; UROS, uroporphyrinogen-III synthase; UROD, uroporphyrinogen decarboxylase; CPOX, coproporphyrinogen oxidase; PPOX, protoporphyrinogen oxidase; FECH, ferrochelatase.)

Right of the core: Porphyrias resulting from disruption of enzyme production. (ADP, aminolevulinic acid dehydratase porphyria; AIP, acute intermittent porphyria; CEP, congenital erythropoietic porphyria; PCT, porphyria cutanea tarda; HCP, hereditary coproporphyria; VP, variegate porphyria; EPP, erythropoietic protoporphyria.)

The final product, the heme, exerts control over the whole pathway via a negative feedback mechanism on the first enzyme - ALAS (indicated by the circle with the minus symbol). 
whole life without experiencing any porphyria symptoms. ${ }^{10}$

An acute attack usually occurs following an exposure to any one of the known precipitating factors. Most known precipitating factors are medications metabolized by the cytochrome $\mathrm{P} 450$ systemwhich are regarded as unsafe for porphyria patients.

Other factors include alcohol use, infections, low caloric intake, and changes in sex hormone balance during the menstrual cycle. ${ }^{11,12}$

Each of these precipitating factors induces ALAS1, either directly ${ }^{13,14}$ or indirectly by increasing demand for hepatic heme, mainly through the consumption of CYT P450 enzymes. ${ }^{1}$

Low carbohydrate intake might induce ALAS1 via peroxisome proliferator-activated receptor gamma coactivator 1- $\alpha$ (PGC-1 $\alpha)$, a protein which directly induces transcription of ALAS1. ${ }^{15}$

When ALAS1 is up-regulated, the heme synthesis is accelerated and the deficient enzyme becomes a rate-limiting one. This leads to excess of heme precursors preceding the defective step.

Animal models5,16,17 and clinical evidence 4 support the theory that delta aminolevulinic acid is neurotoxic, leading to the central, peripheral, and autonomic nervous system symptoms seen in an acute attack. In addition, some studies support the hypothesis suggesting that some of the symptoms of an acute attack might be mediated by increased serotonergic activity. 5 Elevated levels of blood tryptophan and $5-\mathrm{OH}$ tryptamine were reported in AIP patients, ${ }^{18}$ indicating abnormal tryptophan metabolism.

While, from the clinical point of view, acute porphyria attacks of all three types have similar symptoms and are indistinguishable, since they differ from each other in the defective enzyme, each subtype of porphyria has its own typical pattern of heme precursor excretion, which enables biochemical distinction between the three.7

The majority of acute attacks begin as a combination of abdominal pain, mild mental symptoms, such as severe fatigue and inability to concentrate, with or without autonomic dysfunction. ${ }^{2,19}$

Although all components of the peripheral, central, and autonomic nervous systems have been reported to be involved in an acute porphyria attack, the most common symptoms are severe abdominal pain, nausea, vomiting, and constipation. Tachycardia, hypertension, and signs of increased sympathetic activity are often associated with abdominal pain. 3 Hyponatremia occurs in $40 \%$ of patients, probably as a result of inappropriate anti-diuretic hormone secretion syndrome. Additional factors that might contribute to hyponatremia include vomiting and resuscitation with high volumes of dextrose solutions given intravenously. ${ }^{1}$ Seizures, which are characteristic in severe attacks, may be due to severe hyponatremia, or, less commonly, due to posterior reversible encephalopathy syndrome (PRES). ${ }^{20}$

Liver enzymes might be mildly elevated during an attack. ${ }^{19}$ Severe attacks may also present with muscular weakness and or mental disturbance, such as anxiety, disorientation, or hallucinations. ${ }^{1,2}$ In rare cases of AIP, psychosis may be the only clinical manifestation. ${ }^{21,22}$

If a patient is not diagnosed early in the course of an attack, these symptoms can become very severe with full paralysis, respiratory failure, seizures, and even death.

Historically, the purple color of porphyrins, causing the dark colored urine in porphyria patients due to oxidation of PBG to uroporphyrin and porphobilin, ${ }^{23}$ gave the disease its name "porphyria."

Commonly reported symptoms can be found in more detail in Table 1.

\section{Acute Porphyria Attack Diagnosis}

The most rapid and accurate way to diagnose an acute porphyria attack is to measure urinary ALA and PBG levels, which are highly elevated during an acute attack. However, it should be pointed out that, in ADP porphyria, only urinary ALA and not PBG values will be increased.

Once diagnosis has been made, then full biochemical evaluation, using stool, urine, and blood samples, is necessary to differentiate the type of acute porphyria affecting the patient (Figure 2).7

\section{Latent Acute Porphyria Diagnosis}

Biochemical studies, performed on urine, feces, and blood, may identify each of the common acute porphyrias-AIP, HCP, and VP-even in silent patients.

Genetic testing is now available for all acute hepatic porphyrias following biochemical diagnosis, allowing family members to be screened for the specific mutation. Once a family member has been 
Table 1. Clinical Manifestations of Acute Attacks, with Symptoms Listed in the Order of Incidence In Each Box Separately. ${ }^{19}$

\begin{tabular}{|c|c|}
\hline Clinical Manifestation & Symptoms in Order of Incidence \\
\hline Autonomic Dysfunction & $\begin{array}{l}\text { Abdominal pain } \\
\text { Tachycardia } \\
\text { Hypertension } \\
\text { Constipation } \\
\text { Vomiting and nausea } \\
\text { Bladder paresis }\end{array}$ \\
\hline Peripheral Neuropathy & $\begin{array}{l}\text { Pain in the back and limbs } \\
\text { Pareses/muscle weakness } \\
\text { Low/absent tendon reflexes } \\
\text { Respiratory paresis } \\
\text { Cranial neuropathy } \\
\text { Neuropathic sensory loss }\end{array}$ \\
\hline Encephalopathy & $\begin{array}{l}\text { Mild mental symptoms } \\
\text { Seizures } \\
\text { Coma } \\
\text { Blurred vision } \\
\text { Babinski signs } \\
\text { Nystagmus } \\
\text { Cerebellar ataxia }\end{array}$ \\
\hline Metabolic Changes & $\begin{array}{l}\text { Transaminases increased } \\
\text { Pink/red/dark urine } \\
\text { Hyponatremia }\end{array}$ \\
\hline
\end{tabular}

diagnosed with porphyria, he is considered a "latent patient" and should be advised to avoid all known manageable environmental factors which may trigger an attack.

At the time of writing, there have been over 400 different mutations identified only in AIP, and yet there is little evidence that a certain genotype could predict the phenotype.

\section{Acute Attack Treatment}

As mentioned earlier, acute porphyria attacks may be life-threatening if not treated, due to severe neurological complications such as motor paralysis. Therefore, whenever an acute porphyria attack is diagnosed, the patient should be treated as early as possible.

The initial step of porphyria treatment should be to determine and withdraw any possible trigger.

Specific treatment, aimed at stopping the acceleration in heme synthesis which occurs during an acute attack, is targeted to down-regulate ALAS1 activity. This might be achieved, in very mild cases, by hydration and administration of carbohydrates, or much more effectively, in severe attacks, by bloodderived heme, such as Normosang (Orphan Europe, Puteaux, France) in Europe or Hematin (Xellia Pharmaceuticals, Nourth Carolina, USA) in the US. ${ }^{2}$

Palliative treatments given during an acute attack for pain, nausea, and other symptom relief should be performed using only "safe" drugs for porphyria patients. Data regarding safe drugs can be found on several web sites (including The Drug Database for Acute Porphyria at: www.drugs-porphyria.org).

Once an attack is over, a patient will usually gradually return to normal with no residual symptoms between attacks, unless exposure to precipitating factors is not withdrawn.

Some $3 \%-5 \%$ of newly diagnosed patients may suffer recurrent acute attacks. ${ }^{10,24}$ Management of these patients is challenging and, so far, has been based on one of the treatments below: 


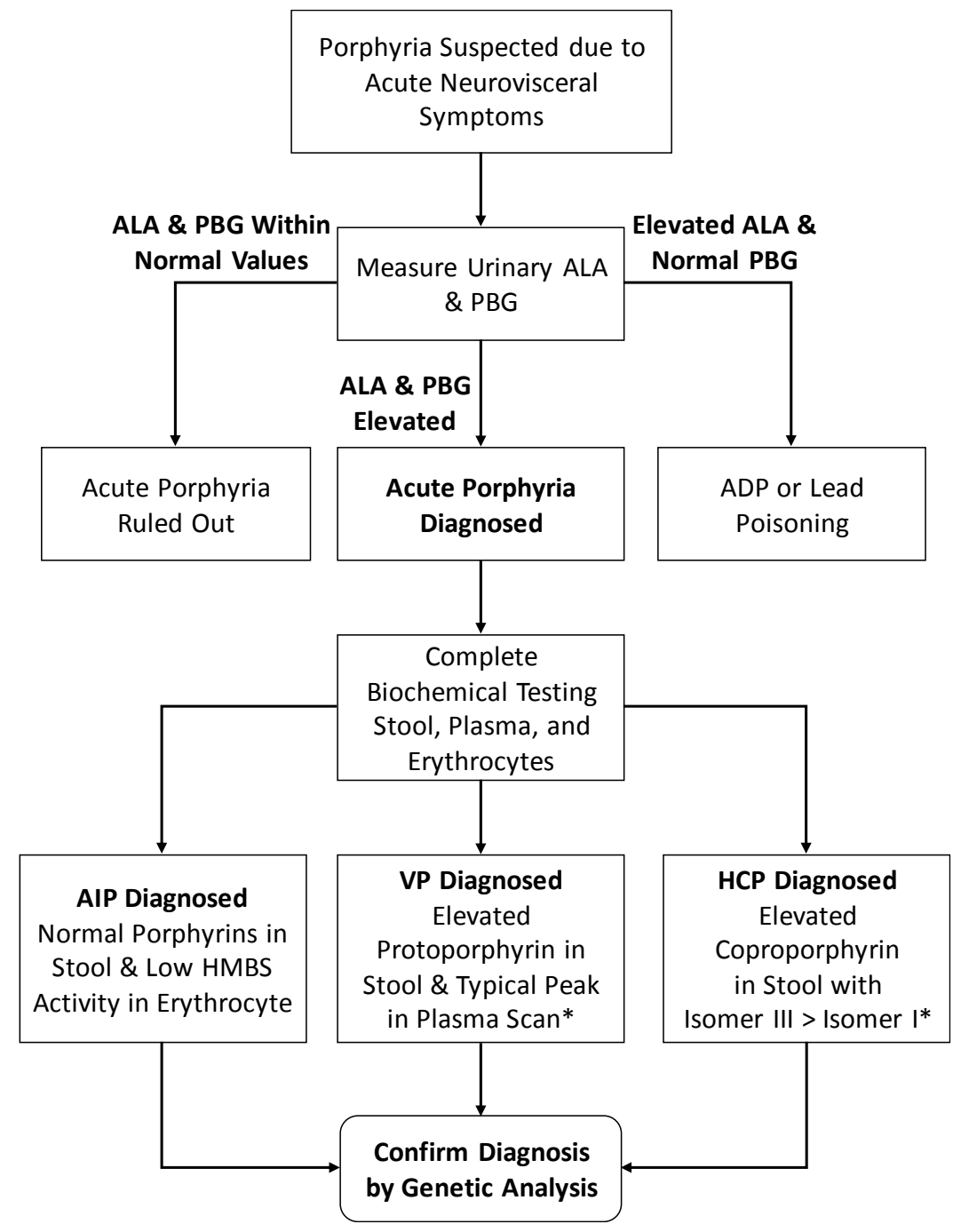

Figure 2. Diagnosis Algorithm for Acute Neurovisceral Symptoms Leading to Suspicion of Porphyria.

* Biochemical markers also detected in the latent phase.

ADP, aminolevulinic acid dehydratase porphyria; AIP, acute intermittent porphyria; ALA, aminolevulinic acid; HCP, hereditary coproporphyria; HMBS, hydroxymethylbilane synthase; PBG, porphobilinogen; VP, variegate porphyria.

1. Heme therapy which could be given as needed, or in severe refractory patients given at regular intervals as prophylactic therapy. 25 Complications of long-term heme infusions could include: iron overload, thrombotic superficial veins which could appear after transfusions, and dependence on the exogenic heme in some patients. ${ }^{26}$

2. In women suffering from menstrual cycle-related acute attacks, gonadotropin-releasing hormone (GnRH) agonist treatment could be given to avoid the attacks. ${ }^{27}$ Since these recurrent attacks tend to target young women, this treatment should be given only after considering other choices and discussing the physical and emotional issues carefully.

3. When no standard treatment is helpful and quality of life is poor, liver transplantation could be an option. Currently over 10 AIP patients have undergone liver transplantation since 2004..$^{10,26}$ The potential of long- and short-term risks of liver transplantation and the prolonged immunosuppression leave this drastic option as a last resort. ${ }^{10}$

Lately, a subcutaneous therapy, based on RNAi targeted to silence ALAS1 expression (Givosiran, Alnylam Pharmaceuticals, Cambridge, MA, USA), 
has been developed and so far has shown preliminary promising results. This drug has recently been granted Food and Drug Administration (FDA) breakthrough therapy status.

Some patients are at risk for late complications. One of these complications includes chronic abdominal pain which is usually a late complication of recurrent acute attacks. It is important to differentiate this pain from an acute attack since it rarely responds to the same treatment. ${ }^{28}$

As for other possible complications, several studies suggest that patients with AIP are at higher risk for chronic kidney disease, ${ }^{29,30}$ with evidence showing this to be due to vascular toxicity of porphyrin metabolites to the tubular interstitium. ${ }^{31}$

There is also evidence showing an association between hepatocellular carcinoma and acute porphyria. This evidence has been mainly shown in northern European patients with AIP, although there are case reports in patients with $\mathrm{VP}$ and $\mathrm{HCP}^{2}$ too. Although the data are still lacking, currently, many porphyria services offer screening for porphyria patients over the age of 50 .

\section{Epidemiology}

As mentioned earlier, AIP is the most common acute hepatic porphyria affecting all ethnic and racial groups. In Europe the prevalence of symptomatic diagnosed AIP has been shown to be 5.9 per million. ${ }^{24}$ The actual prevalence of pathogenic mutations is unknown and thought to be much higher, with a clinical penetrance of only $1 \%-10 \% .33-35$

Attacks occur more commonly in young females after puberty than in men and are rare after menopause. ${ }^{29}$ In AIP this female tendency is strongly observed, with up to $80 \%-90 \%$ of patients being female, ${ }^{2}$ while, in our experience, this is not as obvious in the case of other acute porphyrias.

Variegate porphyria (VP) is the second most common acute hepatic porphyria, and HCP is the third. ${ }^{24}$

While, as mentioned, all these acute porphyrias are inherited as an autosomal dominant disease, ADP is inherited in an autosomal recessive way, therefore being an extremely rare porphyria with only six certain reported cases confirmed by DNA studies. ${ }^{36}$ This type of porphyria results from a deficiency of the aminolevulinic acid dehydratase (ALAD) enzyme, resulting in a unique biochemical pattern during an acute attack with elevated urinary ALA level and a normal urinary PBG level (Figure 1).

\section{Homozygous Acute Porphyrias}

Reported cases of homozygous AIP, $37 \mathrm{HCP}, 3^{8}$ and VP39 are rare. Homozygous AIP is associated with mental retardation, homozygous HCP with photosensitivity and neurological symptoms, and homozygous VP with severe photosensitivity and finger shortening.

\section{Lead Poisoning}

An acquired ALAD inhibition, mimicking ADP, occurs in lead poisoning, in which symptoms may mimic those of acute porphyria. ${ }^{40,41}$ Treatment in this case should first address washing out the poisoning factor.

\section{CUTANEOUS PORPHYRIAS}

\section{Porphyria Cutanea Tarda}

Porphyria cutanea tarda (PCT) is the most common of the cutaneous porphyrias and is caused by a deficient level of uroporphyrinogen decarboxylase (UROD) (Figure 1). It can be subdivided into three types:

1. A sporadic acquired form constitutes $70 \%-80 \%$ of the cases. This sporadic form arises from known risk factors. These include: alcohol abuse, chronic hepatitis C, HIV infection, hemochromatosis, end-stage renal disease, and estrogen therapy. In the sporadic form, UROD activity is deficient in the liver, but not in erythrocytes.

2. A familial form constitutes about $20 \%$ of the cases and results from heterozygous mutation in one allele of UROD. The hereditary mutation reduces UROD activity in all tissues, but affected patients usually do not develop an overt disease unless exposed to additional risk factors.

3. A minority of the cases (less than $5 \%$ ) have a positive family history in spite of normal erythrocyte UROD activity, implying that in these cases a genetic defect or common environmental factors remain unknown. 42

Porphyria cutanea tarda is associated with cutaneous photosensitivity, and its clinical manifestations include blisters, bullae, or vesicular lesions restricted to sun-exposed areas (face, hands, forearms, and lower legs). The skin becomes very fragile, with superficial erosions covered by crust following minimal trauma. 43 
While PCT has no neurovisceral manifestations, it is important to point out that patients with VP and HCP may display skin symptoms similar to those seen in PCT patients. Reliable biochemical testing to accurately diagnose the type of porphyria is essential, in order to avoid a possible acute attack of VP or HCP (Figure 3).

Homozygous familial PCT is extremely rare and is known as hepato-erythropoietic porphyria (HEP). This type of PCT is much more severe and develops during childhood, while the familial and sporadic forms appear at mid to late adulthood. 44

\section{Treatment}

Until plasma porphyrin levels normalize, patients should avoid direct sunlight.

The first therapeutic method should include treating and avoiding exposure to all the abovementioned risk factors such as alcohol, smoking, estrogen, etc. In hepatitis C virus (HCV)-positive patients, antiviral treatment may cure both the hepatitis and the PCT.43

Besides controlling the risk factors, current direct treatments which are very effective in reducing

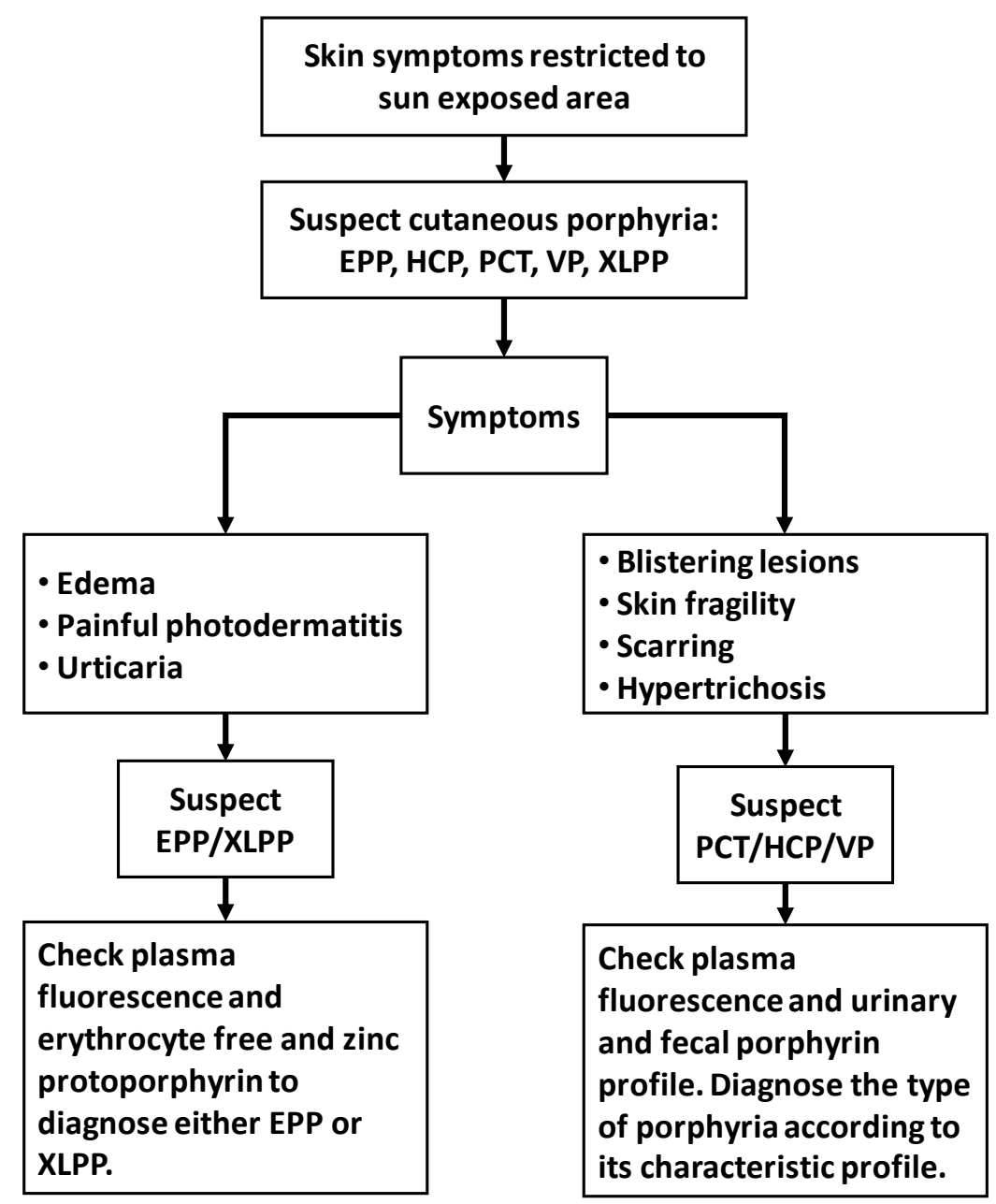

Figure 3. Diagnosis Algorithm for Porphyria Cutaneous Symptoms.

ADP, aminolevulinic acid dehydratase porphyria; AIP, acute intermittent porphyria; CEP, congenital erythropoietic porphyria; EPP, erythropoietic protoporphyria; HCP, hereditary coproporphyria; PCT, porphyria cutanea tarda; VP, variegate porphyria; XLPP, X-linked protoporphyria. 
porphyrin levels include: (1) iron reduction, either by phlebotomy, or, less effectively, by iron chelation; and (2) low-dose antimalarials, such as hydroxychloroquine or chloroquine, drugs that act as mobilizers of porphyrins from the liver, by transforming hepatocyte porphyrins into water-soluble complexes which excrete in the urine. Since initially there is an elevation in porphyrin levels some patients suffer initially from an increase in photosensitivity.

\section{Erythropoietic Protoporphyria}

Erythropoietic protoporphyria (EPP) is a chronic erythropoietic porphyria, associated with excess accumulation of free protoporphyrin in erythroid cells, plasma, skin, and liver. Its clinical manifestation is mainly acute photosensitivity appearing as early as 20 minutes after exposure to light. This is a non-scarring reaction manifesting as pain, redness, and swelling of the exposed skin surface. 45 Besides the cutaneous symptoms, patients often exhibit a slight microcytic, hypochromic anemia. ${ }^{46}$ A small percentage (approximately $2 \%$ ) of EPP patients may develop hepatobiliary complications in addition to the cutaneous symptoms.

The genetic cause of the disease, in the majority of patients, is a partial deficiency in ferrochelatase, the last enzyme in the heme biosynthetic pathway. ${ }^{47}$ The inheritance of ferrochelatase deficiency EPP is complex and is usually associated with an inheritance of a mutated ferrochelatase $(\mathrm{FECH})$ allele from one parent, and a low-expression allele (IVS$48 \mathrm{~T} / \mathrm{C}$ ) from the other. ${ }^{48}$ Consequently, the residual activity of ferrochelatase is decreased below a critical threshold, leading to an overt disease of EPP. However, about $2 \%-10 \%$ of cases result from gainof-function mutations in the ALAS2 gene. Since the ALAS2 gene is located on chromosome X, EPP associated with ALAS2 gain-of-function is inherited in a dominant X-linked way, due to which it is known as X-linked protoporphyria (XLPP). In female carriers, the phenotypic manifestation is directly influenced by the X-chromosomal inactivation. 49

The prevalence of EPP worldwide is estimated to be $1: 75,000$ to $1: 200,000$, and is probably influenced by the frequency of IVS3-48C FECH allele in a given population..$^{0}$

In Israel, the frequency of IVS3-48C FECH allele was investigated in the Ashkenazi population and was estimated to be similar to that found in European populations, $8 \% .5^{11}$ Autosomal recessive inheritance, associated with mutations in both alleles of
FECH, has been reported in about $4 \%$ of the cases..$^{2}$ Patients with this recessive form of EPP usually exhibit palmar keratoderma. 53

\section{Management}

The main strategy in EPP management is avoiding exposure to light. Opaque sunscreen, barrier clothing, and protective tinted glass for cars and windows, is recommended. It is important to note that since skin symptoms are associated with exposure to light within the visible range, conventional sunblock creams are usually ineffective. Some products containing titanium dioxide might be of benefit.54,55 Some data have shown beta carotene therapy to be effective in reducing skin symptoms, although in a controlled study this effect has been shown to be minimal. 56

Narrowband UVB phototherapy aimed to produce "skin hardening" may provide useful protection preventing cutaneous phototoxicity.54 Afamelanotide, a drug which has been recently developed (Clinuvel Inc., Melbourne, Australia), is an alphamelanocyte-stimulating hormone analogue and is already in use, with good results. 57

\section{Liver Failure}

The proportion of EPP patients who develop severe liver complications is estimated to be about $5 \% .^{2}$ In these cases, removing protoporphyrin by exchange transfusions and plasmapheresis has been used as a bridge to liver transplantation. It is important to point out that, in surgical procedures, the use of protective filters for lights in the operating room is recommended, in order to avoid phototoxic damage to internal organs.55 Immunization for hepatitis A and $\mathrm{B}$ is recommended as well.55

In all types of cutaneous porphyria, avoidance of sunlight might contribute to vitamin D deficiency 58,59 and lower bone density. ${ }^{60}$ It is highly recommended to monitor serum vitamin $\mathrm{D}$ status and treat with supplementations if needed.

\section{Congenital Erythropoietic Porphyria}

Congenital erythropoietic porphyria (CEP), also known as Günther's disease, is an extremely rare autosomal recessive cutaneous porphyria, with a prevalence of less than 1 per million. This kind of porphyria is caused by deficient activity of uroporphyrinogen-III synthase (UROS), the fourth enzyme in the heme biochemical pathway. The clinical manifestations start in early infancy and may affect different organs. They include: skin fragility, blister- 
ing, and scarring; facial hypertrichosis and/or scarring alopecia; hemolytic anemia or pancytopenia; scarring of fingers, resorption of finger tips; photophobia and loss of eye lashes; erythrodontia; neonatal jaundice; and splenomegaly. ${ }^{61}$

Treatment for CEP starts with sun protection to avoid skin trauma. Since the symptoms may involve several systems, the treatment depends on the affected organ. So far, the only successful curative strategy reported is bone marrow transplantation. $5^{8}$

\section{CONCLUSION}

The porphyrias are a group of diseases that may exhibit various symptoms, according to the type of disease. Consequently, physicians from many disciplines may meet undiagnosed porphyria patients of any type. Awareness of porphyria acute neurovisceral attacks or cutaneous symptoms may lead to an accurate diagnosis and, as a result, to prompt treatment, which might be life-saving.

\section{REFERENCES}

1. Besur S, Schmeltzer P, Bonkovsky HL. Acute porphyrias. J Emerg Med 2015;49:305-12. Crossref

2. Bissell DM, Anderson KE, Bonkovsky HL. Porphyria. N Engl J Med 2017;377:862-72. Crossref

3. Karim Z, Lyoumi S, Nicolas G, Deybach JC, Gouya L, Puy H. Porphyrias: a 2015 update. Clin Res Hepatol Gastroenterol 2015;39:412-25. Crossref

4. Bissell DM, Lai JC, Meister RK, Blanc PD. Role of delta-aminolevulinic acid in the symptoms of acute porphyria. Am J Med 2015;128:313-17. $\underline{\text { Crossref }}$

5. Meyer UA, Schuurmans MM, Lindberg RL. Acute porphyrias: pathogenesis of neurological manifestations. Semin Liver Dis 1998;18:43-52. Crossref

6. Schulenburg-Brand D, Katugampola R, Anstey AV, Badminton MN. The cutaneous porphyrias. Dermatol Clin 2014;32:369-84. Crossref

7. Woolf J, Marsden JT, Degg T, et al. Best practice guidelines on first-line laboratory testing for porphyria. Ann Clin Biochem 2017;54:188-98. Crossref

8. Besur S, Hou W, Schmeltzer P, Bonkovski HL. Clinically important features of porphyrin and heme metabolism and the porphyrias. Metabolites 2014;4: 977-1006. Crossref

9. Badminton MN, Elder GH. Molecular mechanisms of dominant expression in porphyria. J Inherit Metab Dis 2005;28: 277-86. Crossref
10. Stein PE, Badminton MN, Rees DC. Update review of the acute porphyrias. Br J Haematol 2017;176:52738. Crossref

11. Liu YP, Lien WC, Fang CC, Lai TI, Chen WJ, Wang HP. ED presentation of acute porphyria. Am J Emerg Med 2005;23:164-7. Crossref

12. Kauppinen R, Mustajoki P. Prognosis of acute porphyria: occurrence of acute attacks, precipitating factors, and associated diseases. Medicine 1992;71:1-13. Crossref

13. Anderson KE, Bradlow HL, Sassa S, Kappas A. Studies in porphyria: VIII. Relationship of the $5 \alpha^{-}$ reductive metabolism of steroid hormones to clinical expression of the genetic defect in acute intermittent porphyria. Am J Med 1979;66:644-50. Crossref

14. Doss MO, Kuhnel A, Gross U. Alcohol and porphyrin metabolism. Alcohol Alcohol 2000;35:109-25. Crossref

15. Handschin C, Jiandie L, Rhee J, et al. Nutritional regulation of hepatic heme biosynthesis and porphyria through PGC-1 $\alpha$. Cell 2005;122:505-15.

16. Bremmam MJ, Cantrill RC. Delta-aminolaevulinic acid is a potent agonist for GABA autoreceptors. Nature 1979;280:514-15. $\underline{\text { Crossref }}$

17. Emanuelli T, Pagel FW, Alves LB, Regner A, Souza DO. 5-Aminolevulinic acid inhibits [3H] muscimol binding to human and rat brain synaptic membranes. Neurochem Res 2001;26:101-5. Crossref

18. Puy H, Deybach JC, Baudry P, Callebert J, Touitou Y, Nordmann Y. Decreased nocturnal plasma melatonin levels in patients with recurrent acute intermittent porphyria attacks. Life Sci 1993;53:621-7.

19. Pischik E, Kauppinen R. Neurological manifestations of acute intermittent porphyria (AIP). Cell Mol Biol (Noisy-le-grand) 2009;55:72-83.

20. Zao B, Wei Q, Wang Y, Chen Y, Shang H. Posterior reversible encephalopathy syndrome in acute intermittent porphyria. Pediat Neurol 2014;51:457-60. Crossref

21. Kumar B. Acute Intermittent porphyria presenting solely with psychosis: a case report and discussion. Psychosomatics 2012;53:494-8.

22. Ellencweig N, Schoenfeld N, Zemishlany Z. Acute intermittent porphyria: psychosis as the only clinical manifestation. Isr J Psychiatry Relat Sci 2006;43:526.

23. Sassa S. Modern diagnosis and management of the porphyrias. $\mathrm{Br} \mathrm{J}$ Haematol 2006;135:281-92. Crossref 
24. Elder G, Harper P, Badminton M, Sandberg S, Deybach JC. The incidence of inherited porphyrias in Europe. J Inherit Metab Dis 2013;36:849-57. $\underline{\text { Crossref }}$

25. Anderson KE, Collins S. Open-label study of hemin for acute phorphyria: clinical practice. Am J Med 2006;119:801.e19-24. Crossref

26. Pischik E, Kauppinen R. An update of clinical management of acute intermittent porphyria. App Clin Genet 2015;8:201-14. $\underline{\text { Crossref }}$

27. Innala E, Backstrom T, Bixo M, Andersson C. Evaluation of gonadotropin-releasing hormone agonist treatment for prevention of menstrual-related attacks in acute porphyria. Acta Obstet Gynecol Scand 2010;89:95-100. $\underline{\text { Crossref }}$

28. Bonkovsky HL, Maddukuri VC, Yazici C, et al. Acute porphyrias in the USA: features of 108 subjects from porphyrias consortium. Am J Med 2014;127:1233-41. Crossref

29. Church SE, McColl KE, Moore MR, Youngs GR. Hypertension and renal impairment as complications of acute porphyria. Nephrol Dial Transplant 1992;7: 986-90.

30. Andersson C, Wikberg A, Stegmayr B, Lithner F. Renal symptomatology in patients with acute intermittent porphyria: a population based study. J Intern Med 2000;248:319-25. Crossref

31. Pallet N, Mami L, Schmitt C, et al. High prevalence of and potential mechanisms for chronic kidney disease in patients with acute intermittent porphyria. Kidney Int 2015;88:386-95. Crossref

32. Stewart MF. Review of hepatocellular cancer, hypertension and renal impairment as late complications of acute porphyria and recommendations for patient follow-up. J Clin Pathol 2012;65:976-80. Crossref

33. Andersson C, Floderus Y, Wikberg A, Lithner F. The W198X and R173W mutations in the porphobilinogen deaminase gene in acute intermittent porphyria have higher clinical penetrance than R167W: a populationbased study. Scand J Clin Lab Invest 2000;60:643-8. Crossref

34. Chen B, Solis-Villa C, Hakenberg J, et al. Acute intermittent porphyria: predicted pathogenicity of HMBS variants indicates extremely low penetrance of the autosomal dominant disease. Hum Mutat 2016;37:1215-22. $\underline{\text { Crossref }}$

35. Nordmann Y, Puy H, Da Silva V, et al. Acute intermittent porphyria: prevalence of mutations in the porphobilinogen deaminase gene in blood donors in France. J Intern Med 1997;242:213-17. Crossref

36. Doss MO, Stauch T, Gross U, et al. The third case of Doss porphyria (delta-amino-levulinic acid dehydra- tase deficiency) in Germany. J Inherit Metab Dis 2004;27:529-36. $\underline{\text { Crossref }}$

37. Hessels J, Voortman G, van der Wagen A, van der Elzen C, Scheffer H, Zuijderhoudt FM. Homozygous acute intermittent porphyria in a 7 year old boy with massive excretions of porphyrins and porphyrin precursors. J Inherit Metab Dis 2004;27:19-27. Crossref

38. Martasek P, Nordmann Y Grandchamp B. Homozygous hereditary coproporphyria caused by an arginine to tryptophane substitution in coproporphyrinogen oxidase and common intragenic polymorphisms. Hum Mol Genet 1994;3:477-80. $\underline{\text { Crossref }}$

39. Poblete-Gutierrez P, Wolff C, Farias R, Frank J. A Chilean boy with severe photosensitivity and finger shortening: the first case of homozygous porphyria in South America. Br J Dermatol 2006;154:368-71. $\underline{\text { Crossref }}$

40. Dyer J, Garnick DP, Inglis A, Pye IF. Plumboporphyria (ALAD deficiency) in a lead worker: a scenario for potential diagnostic confusion. Br J Ind Med 1993;50:1119-21. Crossref

41. Mamet R, Sztern M, Rachmel A, Stahl B, Flusser D, Schoenfeld N. Lead poisoning: a new biochemical perspective on the differentiation between acquired and hereditary neuroporphyria. Clin Chem 2001; 47:1710-13.

42. Bonkovsky HL, Poh-Fitzpatrick M, Pimstone N, et al. Porphyria cutanea tarda, hepatitis $\mathrm{C}$, and HFE gene mutations in north America. Hepatology 1998;27: 1661-9. $\underline{\text { Crossref }}$

43. Takata K, Shakado S, Sakamoto K, et al. Disappearance of multiple hyperechoic liver nodules in sporadic porphyria cutanea tarda after treatment with ledipasvir/sofosbuvir for hepatitis C. Clin J Gastroenterol 2017;10:459-63. $\underline{\text { Crossref }}$

44. Farrag MS, Midula I, Richard E, Sauder V, De Verneuil H, Martasek P. Hepatoerythropoietic porphyria caused by a novel homoallelic Mutation in Uroporphyrinogen decarboxylase gene in Egyptian patients. Folia Biol (Praha) 2015;61:219-26.

45. DeLeo VA, Poh-Fitzpatrick M, Mathews-Roth M, Harber LC. Erythropoietic protoporphyria. 10 years' experience. Am J Med 1976;60:8-22. $\underline{\text { Crossref }}$

46. Holme SA, Worwood M, Anstey AV, Elder GH, Badminton MN. Erythropoiesis and iron metabolism in dominant erythropoietic protoporphyria. Blood 2007;110:4108-10. $\underline{\text { Crossref }}$

47. Balwani M, Doheny D, Bishop D, et al. Loss of function ferrochelatase and gain of function erythroidspecific 5 -aminolevulinate synthase mutation causing erythropoietic protoporphyria and X-linked proto- 
porphyria in North American patients reveal novel mutations and high prevalence of X-linked protoporphyria. Mol Med 2013;19:26-35. $\underline{\text { Crossref }}$

48. Brancaleoni V, Balwani M, Granata F, et al. Xchromosomal inactivation directly influences the phenotypic manifestation of X-linked protoporphyria. Clin Genet 2016;89:20-6. Crossref

49. Gouya L, Puy H, Robreau AM, et al. The penetrance of dominant erythropoietic protoporphyria is modulated by expression of wildtype FECH. Nature Genet 2002;30:27-8. $\underline{\text { Crossref }}$

50. Gouya L, Marine-Schmitt C, Robreau AM, et al. Contribution of a common single nucleotide polymorphism to the genetic predisposition for erythropoietic protoporphyria. Am J Hum Genet 2006;78:2-14. Crossref

51. Schneder-Yin X, Mamet R, Minder EI, Schoenfeld N. Biochemical and molecular diagnosis of erythropoietic protoporphyria in an Ashkenazi Jewish family. J Inherit Metab Dis 2008;31(Suppl 2):S3637. $\underline{\text { Crossref }}$

52. Holme SA, Whatley SD, Roberts AG, et al. Seasonal palmar keratoderma in erythropoietic protoporphyria indicates autosomal recessive inheritance. J Invest Dermatol 2009;129:599-605.

53. Minder EI, Schneider-Yin X, Mamet R, et al. A homoallelic FECH mutation in a patient with both erythropoietic protoporphyria and palmar keratoderma. J Eur Acad Dermatol Venerol 2010;24:134953. $\underline{\text { Crossref }}$

54. Dawe R. An overview of the cutaneous porphyrias. F100oRes 2017;6:1906. Crossref
55. Balwany M, Bloomer J, Desnick R, Balwani M, Bloomer J, Desnick R; Porphyrias Consortium of the NIH-Sponsored Rare Diseases Clinical Research Network. Erythropoietic Protoporphyria, Autosomal Recessive. In: Adam MP, Ardinger HH, Pagon RA, et al., eds. SourceGeneReviews® [Internet]. Seattle (WA): University of Washington, Seattle; 1993-2018. [Last update: September 7, 2017].

56. Corbett MF, Herxheimer, A, Magnus IA, Ramsay CA, Kobza-Black A. The long-term treatment with betacarotene in erythropoietic protoporphyria: a controlled trial. Br J Dermatol 1977;97:655-62. $\underline{\text { Crossref }}$

57. Minder EI, Barman-Aksoezen J, Schneider-Yin X. Pharmacokinetics and pharmacodynamics of Afamelanotide and its clinical use in treatment dermatologic disorders. Clin Pharmacokinet 2017;56:815-23. Crossref

58. Holme SA, Anstey AV, Badminton MN, Elder GH. Serum 25-hydroxyvitamin D in erythropoietic protoporphyria. Br J Dermatol 2008;159:211-13. $\underline{\text { Crossref }}$

59. Spet JMC, de Rooij FWM, Wilson JHP, Zandbergen AAM. Vitamin D deficiency in patients with erythropoietic protoporphyria. J Inherit Metab Dis 2010;33 (Suppl 3):S1-4.

6o. Biewenga M, Matawile RHS, Friesema ECH, et al. Osteoporosis in patients with erythropoietic protoporphyria. Br J Dermatol 2017;177:1693-8. Crossref

61. Martinez Peinado C, Díaz de Heredia C, To-Figueras J, et al. Successful treatment of congenital erythropoietic porphyria using matched unrelated hematopoietic stem cell transplantation. Pediatr Dermatol 2013;30:484-9. Crossref 